\title{
Use of the Robson classification to understand the increased risk of cesarean section in case of maternal obesity
}

\author{
Simon Crequit ${ }^{1 *}$, Diane Korb ${ }^{1,2}$, Cécile Morin ${ }^{1}$, Thomas Schmitz ${ }^{1,2}$ and Olivier Sibony ${ }^{1}$
}

\begin{abstract}
Background: The aim of this study was to identify characteristics of pregnant women with obesity that contribute to increased cesarean rate.

Methods: Retrospective cohort in a single academic institution between 2012 and 2019. Women who delivered during this period were classified according to the Robson classification. Women with normal body mass index $(N=11,797)$ and with obesity $(N=2991)$ were compared. The contribution of each Robson group to the overall caesarean rate were compared.

Results: The overall cesarean rate was higher for women with $(28.1 \%)$ than without $(14.2 \%, p<0.001)$ obesity. This result came mainly from Robson group 5 a (history of one cesarean). After adjustment for medical factors within this group, the association between maternal obesity and cesarean during labor was significant.

Conclusions: The higher cesarean rate in women with obesity is explained by Robson group 5a in which obesity is an independent risk factor of in labor cesarean delivery.
\end{abstract}

Keywords: Maternal obesity, Caesarean section, Robson, BMI and cesarean

\section{Background}

Maternal obesity is a major health issue in most of industrialized countries. The rate of obesity among pregnant women has increased from 9.9 to $11.8 \%$ between 2010 [1] and 2016 [2] in France and from 17.6\% in 2003 to $24.5 \%$ in 2014 in the US [3, 4]. Previous studies on women with obesity have demonstrated increased pregnancy complications such as hypertensive disorders, gestational diabetes, macrosomia and stillbirth [5-7]. Recent data on maternal obesity have demonstrated an increase in cesarean section (CS) and an increasing number of elective cesarean delivery [8-10]. Indeed, the CS rate increase in women with obesity is becoming of

\footnotetext{
* Correspondence: crequitsimon@gmail.com

'Department of Gynecology and Obstetrics, Robert Debré University Hospital, AP-HP, 48 boulevard Sérurier, 75019 Paris, France

Full list of author information is available at the end of the article
}

concern given the frequency of this disorder. Unfortunately, these data are often focusing on a small part of the pregnant population with obesity such as primiparas, women developing gestational diabetes or only focus on complications. Yet, there are no available data on the risk of caesarean delivery in this population aiming at identifying subgroups at high risk of CS in order to implement measures to reduce the CS rate. To address this issue the Robson classification [11] constitutes a useful tool to identify the characteristics of women contributing the most to the CS rate in a given population. The latter divides births into 10 groups based on obstetrical history, onset of labor, fetal presentation, number of neonates, and gestational age. It is a standardized and reproducible framework that classifies women in relevant categories for analysis of CS rates.

(c) The Author(s). 2020 Open Access This article is licensed under a Creative Commons Attribution 4.0 International License, which permits use, sharing, adaptation, distribution and reproduction in any medium or format, as long as you give appropriate credit to the original author(s) and the source, provide a link to the Creative Commons licence, and indicate if changes were made. The images or other third party material in this article are included in the article's Creative Commons licence, unless indicated otherwise in a credit line to the material. If material is not included in the article's Creative Commons licence and your intended use is not permitted by statutory regulation or exceeds the permitted use, you will need to obtain permission directly from the copyright holder. To view a copy of this licence, visit http://creativecommons.org/licenses/by/4.0/ The Creative Commons Public Domain Dedication waiver (http://creativecommons.org/publicdomain/zero/1.0/) applies to the data made available in this article, unless otherwise stated in a credit line to the data. 
The aim of this study was to identify the characteristics of the women with obesity that contribute to the overall cesarean rate increase using the Robson classification. The objective was to compare the contribution of each Robson group to the overall cesarean rate between normally weighted and women with obesity to target the group responsible for most of the difference in CS rate. This analysis might indicate in which group efforts have to be made in order to reduce the overall CS rate in women with obesity.

\section{Methods}

\section{Study population}

Using hospital birth records, we identified all women that delivered at a single tertiary care academic institution between January 2012 and December 2019. Stillbirths and neonatal deaths that might modify the mode of delivery were excluded. Triplets (rare event, nonconsensual management), unknown pre-pregnancy body mass index (BMI), according to the World Health Organization's (WHO) definition [12] and patients who couldn't be classified within the Robson classification were excluded (Fig. 1: flow chart). Underweight women $\left(\mathrm{BMI}<18.5 \mathrm{~kg} / \mathrm{m}^{2}\right)$ and overweight women (BMI [2529.9] $\mathrm{kg} / \mathrm{m}^{2}$ ) were excluded because this study focuses on the effect of maternal obesity for which normally weighted women represents the best comparison group. We compared women with obesity $\left(\mathrm{BMI} \geq 30 \mathrm{~kg} / \mathrm{m}^{2}\right)$ to normally weighted women (BMI [18.5-24.9] $\mathrm{kg} / \mathrm{m}^{2}$ ).

\section{Collected data}

Maternal weight was recorded at each prenatal care visit. Total gestational weight gain (GWG) was calculated by

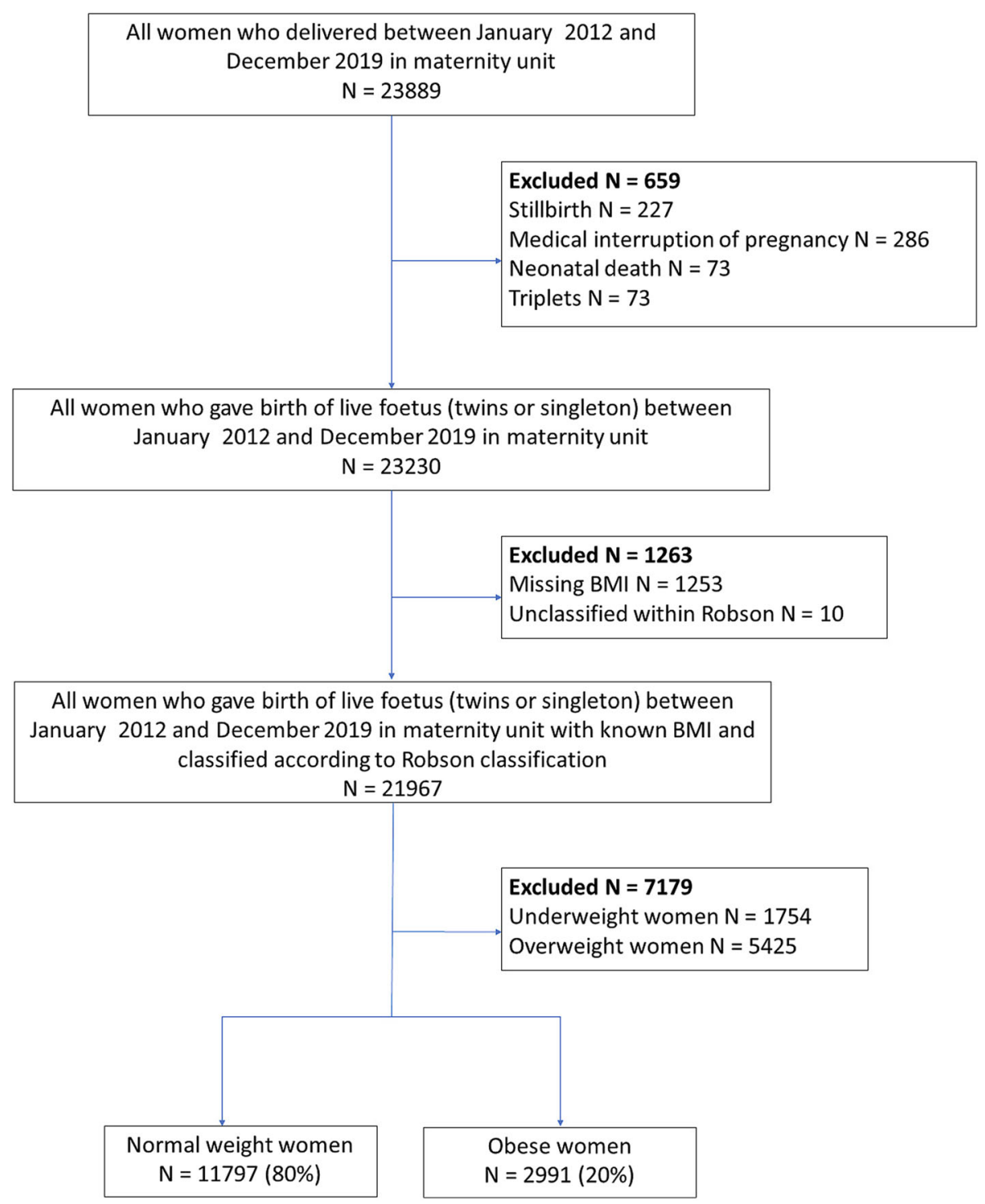

Fig. 1 Flow chart 
subtracting pre-pregnancy weight from the last recorded weight before delivery. Social and demographic characteristics, pregnancy characteristics, labor, maternal and neonatal outcomes were collected from medical records.

The entire medical file was computerized and was completed prospectively at each visit, at delivery, and during the post-partum period by health professional including midwives and obstetrician in charge of the patient. All data were verified at the daily obstetrical staff meeting. During the study period, all women were managed regardless of their BMI regarding the choice of the mode of delivery, induction of labor, and labor management. Gestational diabetes screening was done according to the French recommendation [13].

This information was used to classify women into the 10 Robson groups according to their BMI. All women were classified according to the Robson classification based on obstetrical history, onset of labor, fetal lie, number of fetuses, and gestational age. The analysis was performed using the Robson classification with subdivision in which groups 2 and 4 are separated in cesarean during labor (groups 2a and 4a) and cesarean before labor (groups 2b and 4b). Within Group 5, this classification separate women with one previous cesarean delivery (5a) from women with more than one previous cesarean (5b) because a history of two or more CS is usually considered as an indication for elective cesarean delivery. Moreover, in the maternity at study a history of one CS was not an indication for repeated cesarean delivery. Groups 1 to 4 are usually called low risk groups in terms of cesarean section as they include women delivering at term with a singleton fetus in cephalic presentation whereas groups 5 to 10 are defined as high risk groups of cesarian (history of CS, breech, multiple pregnancy and premature birth).

\section{Outcomes: cesarean delivery rates}

The first analysis consisted in calculating the overall CS rates within the two groups. We then tested if the distribution of patients among the Robson classification differed between the two studied groups. For each Robson group we calculated the relative size of the group (number of deliveries within the group/all deliveries in the BMI group), the CS rate within the group (number of CS within the group/total deliveries within the group) and the contribution of the group to the overall CS rate (CS in each group/total deliveries in the BMI group).

\section{Statistical analysis}

We compared the characteristics of the women, pregnancies, labors and neonates, according to maternal prepregnancy BMI, based on $\mathrm{Chi}^{2}$ or Fisher exact tests for categorical variables and Student's or Wilcoxon rank sum tests for quantitative variables, as appropriate. All tests were two-sided with $P$-values $\leq .05$ defined as statistically significant. Within the Robson categories, analyses were performed for cesarean delivery before labor (vs during labor) and intrapartum cesarean (vs vaginal delivery) among women who labored. Multivariate logistic regression models were created to assess the direct effect of maternal pre-pregnancy BMI on cesarean delivery. The variables introduced into the models were those clinically relevant or found in the literature [14]. Because some of the explaining variables were highly correlated with maternal obesity, the models were tested for multicollinearity. $\mathrm{R}$ software ( $\mathrm{R}$ Development Core Team (2008), version 3.4.4) was used for all analyses.

\section{Results}

Among the 14,788 women included in this analysis, 11,797 (79.8\%) had a normal BMI, and 2991 (20.2\%) had a BMI $\geq 30$ (Fig. 1). Within the group of women with a BMI $\geq 30,2149(71.8 \%)$ were grade 1 obesity (BMI $\left[30-35\left[\mathrm{~kg} / \mathrm{m}^{2}\right), 628(20.9 \%)\right.$ were grade 2 (BMI $\left[35-40\left[\mathrm{~kg} / \mathrm{m}^{2}\right)\right.$ and $214(7.1 \%)$ were grade $3(\mathrm{BMI}>$ $\left.40 \mathrm{~kg} / \mathrm{m}^{2}\right)$.

Women with obesity were more often older than 35 compared to women with normal BMI. Women with BMI $\geq 30$ had more often history of chronic hypertension, diabetes mellitus and were more often multiparous with a history of previous CS than women with normal BMI. Moreover, women with obesity presented higher medical risk level at the beginning of pregnancy compared to normally weighted women. Complications of pregnancy were more frequent for women with obesity compared to normal weight women with significantly more gestational hypertensive disorders (gestational hypertension and preeclampsia) and gestational diabetes (requiring insulin or simple diet). The maternal obesity group significantly exceeded the total GWG recommended in guidelines. Women with a $\mathrm{BMI} \geq 30$ displayed more premature birth before 34 weeks of gestation compared to normally weighted women. Induction was more frequent for women with obesity. Moreover, the induction rates were higher for hypertensive gestational pathologies, fetal indication or maternal indication compared to normal weight women (Table 1).

The overall CS rates were significantly different between the two groups $(28.1 \%$ for women with obesity versus $14.1 \%$ for normal weight women, $p<0.001$, Table 1 ).

Concerning the distribution into the Robson classification, normal weight women were more often classified in groups 1 (Primiparous, single cephalic presentation, spontaneous labor, $\geq 37$ weeks), 2 (Primiparous, single cephalic presentation, $\geq 37$ weeks), 3 (Multiparous, single cephalic presentation, spontaneous labor, $\geq 37$ weeks), and 6 (Primiparous, single 
Table 1 Characteristics of women according to pre-pregnancy BMI

\begin{tabular}{|c|c|c|c|}
\hline & Normal weight & Obesity & $p$ \\
\hline & 11,797 & 2991 & \\
\hline & $\mathrm{N}(\%)$ & $\mathrm{N}(\%)$ & \\
\hline Maternal characteristics & & & \\
\hline Age (years) (mean \pm sd) & $31.82 \pm 5.51$ & $32.88 \pm 5.45$ & $<0.001$ \\
\hline Age class (years) & & & $<0.001$ \\
\hline$<25$ & $1343(11.4)$ & $213(7.1)$ & \\
\hline$[25-30[$ & $3096(26.2)$ & $735(24.6)$ & \\
\hline$[30-35[$ & $3953(33.5)$ & $974(32.6)$ & \\
\hline$\geq 35$ & $3405(28.9)$ & $1069(35.7)$ & \\
\hline Multiparous women & 6639 (56.3) & $2280(76.2)$ & $<0.001$ \\
\hline Previous cesarean delivery & & & $<0.001$ \\
\hline 1 & $1082(9.2)$ & $561(18.8)$ & \\
\hline$\geq 2$ & $220(1.9)$ & $246(8.2)$ & \\
\hline Body mass index before pregnancy $\left(\mathrm{kg} / \mathrm{m}^{2}\right)($ mean $\pm \mathrm{sd})$ & $21.48 \pm 1.66$ & $33.47 \pm 3.54$ & $<0.001$ \\
\hline Smoker & $1585(13.7)$ & 307 (10.6) & $<0.001$ \\
\hline Diabetes mellitus & $94(0.8)$ & $113(3.8)$ & $<0.001$ \\
\hline Chronic hypertension & $116(1.0)$ & $163(5.4)$ & $<0.001$ \\
\hline Bariatric surgery & & & $<0.001$ \\
\hline Bypass & $30(0.3)$ & $36(1.2)$ & \\
\hline Sleeve gastrectomy & $28(0.2)$ & $56(1.9)$ & \\
\hline Gastric band & $14(0.1)$ & $68(2.3)$ & \\
\hline Hight medical risk level at the beginning of pregnancy ${ }^{a}$ & $1880(15.9)$ & $878(29.4)$ & $<0.001$ \\
\hline Pregnancy characteristics & & & \\
\hline Complications of pregnancy ${ }^{b}$ & $1042(8.8)$ & $870(29.1)$ & $<0.001$ \\
\hline Twin pregnancy & $481(4.1)$ & $105(3.5)$ & 0.172 \\
\hline Fetal presentation & & & 0.019 \\
\hline Cephalic & $11,117(94.2)$ & $2782(93.0)$ & \\
\hline Breech & $659(5.6)$ & $198(6.6)$ & \\
\hline Transverse & $20(0.2)$ & $10(0.3)$ & \\
\hline Weight intake during pregnancy (mean $\pm s d$ ) & $12.24 \pm 5.28$ & $7.74 \pm 7.00$ & $<0.001$ \\
\hline Excessive total GWG & $2691(23.7)$ & $1308(45.7)$ & $<0.001$ \\
\hline Gestational diabetes requiring insulin & $162(1.4)$ & $295(9.9)$ & $<0.001$ \\
\hline Gestational diabetes without insulin & $477(4.0)$ & $361(12.1)$ & $<0.001$ \\
\hline In utero transfer & $198(1.7)$ & $57(1.9)$ & 0.439 \\
\hline Premature rupture of membranes & $163(1.4)$ & $76(2.5)$ & $<0.001$ \\
\hline Preterm labor & $725(6.1)$ & $158(5.3)$ & 0.083 \\
\hline Gestational hypertension & $80(0.7)$ & $105(3.5)$ & $<0.001$ \\
\hline Preeclampsia & $233(2.0)$ & $151(5.0)$ & $<0.001$ \\
\hline HELLP syndrome & $15(0.1)$ & $8(0.3)$ & 0.081 \\
\hline Eclampsia & $2(0.0)$ & $1(0.0)$ & 0.57 \\
\hline Suspected small for gestational age & $254(2.2)$ & $40(1.3)$ & 0.005 \\
\hline Cholestasis & $126(1.1)$ & $40(1.3)$ & 0.25 \\
\hline Deep vein thrombosis during pregnancy & $9(0.1)$ & $3(0.1)$ & 0.958 \\
\hline Pulmonary embolism during pregnancy & $1(0.0)$ & $3(0.1)$ & 0.035 \\
\hline
\end{tabular}


Table 1 Characteristics of women according to pre-pregnancy BMI (Continued)

\begin{tabular}{|c|c|c|c|}
\hline & Normal weight & Obesity & $p$ \\
\hline & 11,797 & 2991 & \\
\hline & N (\%) & N (\%) & \\
\hline \multicolumn{4}{|l|}{ Delivery characteristics } \\
\hline \multicolumn{4}{|l|}{ Gestational age at delivery } \\
\hline$<28$ & $70(0.6)$ & $33(1.1)$ & 0.004 \\
\hline$[28-34[$ & $304(2.6)$ & $106(3.5)$ & 0.004 \\
\hline$[34-37[$ & $679(5.8)$ & $186(6.2)$ & 0.35 \\
\hline$[37-41[$ & $8634(73.2)$ & $2124(71.0)$ & 0.02 \\
\hline$\geq 41$ & $2110(17.9)$ & $542(18.1)$ & 0.78 \\
\hline Induction & $2515(21.3)$ & $870(29.1)$ & $<0.001$ \\
\hline Induction indication & & & $<0.001$ \\
\hline Fetal & $826(7.0)$ & $258(8.6)$ & 0.003 \\
\hline Maternal & $155(1.3)$ & $82(2.7)$ & $<0.001$ \\
\hline Premature rupture of membranes & $857(7.3)$ & $251(8.4)$ & 0.04 \\
\hline Post term & $404(3.4)$ & $131(4.4)$ & 0.01 \\
\hline Gestational hypertension or preeclampsia & $246(2.1)$ & $146(4.9)$ & $<0.001$ \\
\hline Non medical & $27(0.2)$ & $2(0.1)$ & 0.11 \\
\hline Delivery mode & & & $<0.001$ \\
\hline Vaginal delivery & 10,130 (85.9) & 2150 (71.9) & \\
\hline Cesarean delivery & 1667 (14.1) & 841 (28.1) & \\
\hline
\end{tabular}

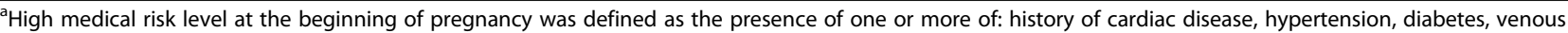
thrombosis, pulmonary embolism, Graves' disease, asthma, homozygous sickle cell anemia, thrombocytopenia, coagulation disorder, a rare or systemic disease, nephropathy, HIV infection, pre-eclampsia, growth restriction, preterm delivery, fetal death or neonatal death

befined as the occurrence of one or more of the following complications: gestational diabetes, pre-eclampsia, eclampsia, HELLP syndrome, venous thrombosis, pulmonary embolism, severe sepsis, convulsions, diabetic ketoacidosis, coagulation disorder, cholestasis of pregnancy

${ }^{c}$ Excessive total gestational weight gain defined as an intake of more than $9 \mathrm{~kg}$ for women with obesity and an intake of more than $15.9 \mathrm{~kg}$ for normal weight

breech presentation) (Tables 2, 3). Women with obesity were more often classified in group 4 (Multiparous, single cephalic presentation, $\geq 37$ weeks, induced or CS before labor), 5 (Multiparous, single cephalic presentation, history of one or more CS, $\geq 37$ weeks, induced or CS before labor), 7 (Multiparous, single breech presentation, including a history of CS) and 10 (Single cephalic presentation, < 37 weeks, including a history of one or more CS), (Tables 2, 3). No differences were found in group 8 (Twin pregnancies, including a history of one or more CS) and 9 (Single transverse or oblique lie, including a history of one or more CS) (Table 3).

Cesarean delivery profiles of the normal weight and the maternal obesity groups are presented in Table 2 and Table 3, respectively. Within each group of the Robson classification women with obesity delivered more often by CS than normal weight women (Table 3). The CS rate between women with obesity and normally weighted women were significantly different for Robson group 1 (respectively $19.1 \%$ versus $8.7 \%, p<0.001$ ), Robson group 2a (41.3\% versus $21.7 \%, p<0.001)$, Robson group 3 (4.7\% versus $1.7 \%, p<0.001)$, Robson group 4a $(12.1 \%$ versus $4.3 \%, p<0.001)$, Robson group 5a (32.9\% versus $22.4 \%, p<0.001)$, Robson group 7 (67.6\% versus $50.4 \%, p<0.01)$ and Robson group 10 (36.9\% versus $23.7 \%, p<0.001$ ).

The Robson category 5 (Multiparous, single cephalic presentation, history of one or more CS, $\geq 37$ weeks) contributed the most to the difference in cesarean rates between normally weighted women and women with obesity with a difference in absolute contribution of $8.4 \%$. This figure is due to a bigger size of the group and a higher CS rate for women with obesity. The overall cesarean rate in group 5a was increased for the women with obesity group compared to the normal weight group: 32.9 and $22.4 \%$ respectively $(p<0.001)$. The results were similar when we distinguished CS before labor (6.8\% for women with obesity versus $4.8 \%$ for normal weight group, $p<0.001$, Table S2) and CS during labor (26.1\% for women with obesity versus $17.5 \%$ for normal weight group, $p<0.001$, Table S2). Women with obesity had more cesarean section for abnormal fetal heart rate (13,7\% versus $9.4 \%$ for normal weight women, $p=0.02$ ) and arrest of labor (13.2\% versus $8.3 \%$ for normal weight women, $p=0.005$, Table S2). Induction rates were 
Table 2 Cesarean delivery profiles of women with normal BMl using Robson classification

\begin{tabular}{|c|c|c|c|c|c|c|}
\hline Group* & $\begin{array}{l}N \text { CS in } \\
\text { group }\end{array}$ & $\begin{array}{l}\text { Total } N \text { in } \\
\text { group }\end{array}$ & $\begin{array}{l}\text { Group Size } \\
\text { (\%) } 1\end{array}$ & $\begin{array}{l}\text { Group CS rate } \\
\text { (\%) } 2\end{array}$ & $\begin{array}{l}\text { Absolute group contribution to } \\
\text { overall CS rate (\%) } 3\end{array}$ & $\begin{array}{l}\text { Relative group contribution to } \\
\text { overall CS rate (\%) } 4\end{array}$ \\
\hline 1 & 281 & 3226 & 27.3 & 8.7 & 2.4 & 16.9 \\
\hline 2 & 288 & 1130 & 9.6 & 25.5 & 2.4 & 17.3 \\
\hline $\begin{array}{l}2 a \\
\text { (Induced) }\end{array}$ & 234 & 1076 & 9.1 & 21.7 & 2.0 & 14.0 \\
\hline $\begin{array}{l}2 b \\
\text { (Prelabor } \\
\text { CS) }\end{array}$ & 54 & 54 & 0.5 & 100.0 & 0.5 & 3.2 \\
\hline 3 & 68 & 3943 & 33.4 & 1.7 & 0.6 & 4.1 \\
\hline 4 & 51 & 735 & 6.2 & 6.9 & 0.4 & 3.1 \\
\hline $\begin{array}{l}4 a \\
\text { (Induced) }\end{array}$ & 31 & 715 & 6.1 & 4.3 & 0.3 & 1.9 \\
\hline $\begin{array}{l}4 b \\
\text { (Prelabor } \\
\text { CS) }\end{array}$ & 20 & 20 & 0.2 & 100.0 & 0.2 & 1.2 \\
\hline 5 & 360 & 1074 & 9.1 & 33.5 & 3.1 & 21.6 \\
\hline 5.a (1 CS) & 204 & 912 & 7.7 & 22.4 & 1.7 & 12.2 \\
\hline $\begin{array}{l}5.6(>1 \\
\text { CS) }\end{array}$ & 156 & 162 & 1.4 & 96.3 & 1.3 & 9.4 \\
\hline 6 & 150 & 272 & 2.3 & 55.1 & 1.3 & 9.0 \\
\hline 7 & 134 & 266 & 2.3 & 50.4 & 1.1 & 8.0 \\
\hline 8 & 160 & 478 & 4.1 & 33.5 & 1.4 & 9.6 \\
\hline 9 & 20 & 20 & 0.2 & 100.0 & 0.2 & 1.2 \\
\hline 10 & 155 & 653 & 5.5 & 23.7 & 1.3 & 9.3 \\
\hline Total & 1667 & 11,797 & 100.0 & 14.1 & 14.1 & 100.0 \\
\hline
\end{tabular}

*Group 1: primiparous, single cephalic presentation, spontaneous labor, $\geq 37$ weeks

*Group 2: primiparous, single cephalic presentation, $\geq 37$ weeks

*Group 2a: primiparous, single cephalic presentation, $\geq 37$ weeks, induction

*Group 2 b: primiparous, single cephalic presentation, $\geq 37$ weeks, CS before labor

*Group 3: multiparous, single cephalic presentation, spontaneous labor, $\geq 37$ weeks

*Group 4: multiparous, single cephalic presentation, $\geq 37$ weeks

*Group 4a: multiparous, single cephalic presentation, $\geq 37$ weeks, induction

*Group 4b: multiparous, single cephalic presentation, $\geq 37$ weeks, CS before labor

*Group 5: multiparous, single cephalic presentation, history of one or more CS, $\geq 37$ weeks

*Group 5a: multiparous, single cephalic presentation, history of one or more CS, $\geq 37$ weeks, history of one CS

*Group 5b: multiparous, single cephalic presentation, history of one or more CS, $\geq 37$ weeks, history of more than one CS

*Group 6: primiparous, single breech presentation

*Group 7: multiparous, single breech presentation, including a history of CS

*Group 8: twin pregnancies, including a history of one or more CS

*Group 9: single transverse or oblique lie, including a history of one or more CS

*Group 10: single cephalic presentation, $<37$ weeks, including a history of one or more CS

1. $\%=\mathrm{n}$ of women in the group / total $\mathrm{N}$ women delivered in the setting $\times 100$

2. $\%=\mathrm{n}$ of CS in the group / total $\mathrm{N}$ of women in the group $\times 100$

3. $\%=\mathrm{n}$ of CS in the group / total $\mathrm{N}$ of women delivered in the setting $\times 100$

4. $\%=\mathrm{n}$ of CS in the group / total N of CS in the setting $\times 100$

higher for women with obesity in group 5 a $(33,8 \%$ versus $22 \%$ for normally weighted women, $p<0.001$, Table S2) especially for fetal, maternal and gestational hypertensive disorders.

After adjustment, the association between maternal prepregnancy BMI and cesarean delivery before labor in group 5 a was not statistically significant $(\mathrm{aOR}=1.26 \mathrm{CI}$ : [0.762.08], adjustment for maternal age, high medical risk level at the beginning of pregnancy, pregnancy complications Table S3), whereas the association between maternal pre- pregnancy BMI and cesarean delivery during labor in group 5 a was statistically significant $(\mathrm{aOR}=1.43,95 \% \mathrm{CI}$ : $[1.07-$ $1.9]$, adjustment for maternal age, high medical risk level at the beginning of pregnancy, pregnancy complication and induction, Table S4).

Neonates of women with obesity compared with the ones of normally weighted women had more often fetal macrosomia, presented more Apgar score $<7$ at $5 \mathrm{~min}$ and more transfers in NICU or neonatal reanimation (Table 4, Table S5). 
Table 3 Cesarean delivery profiles of women with obesity using Robson classification

\begin{tabular}{|c|c|c|c|c|c|c|}
\hline Group* & $\begin{array}{l}N \text { CS in } \\
\text { group }\end{array}$ & $\begin{array}{l}\text { Total } N \text { in } \\
\text { group }\end{array}$ & Group Size (\%) 1 & Group CS rate (\%)2 & $\begin{array}{l}\text { Absolute group contribution to } \\
\text { overall CS rate (\%) } 3\end{array}$ & $\begin{array}{l}\text { Relative group contribution } \\
\text { to overall CS rate (\%) } 4\end{array}$ \\
\hline 1 & 66 & 346 & $11.6^{* * *}$ & $19.1^{* * *}$ & 2.2 & $7.8^{* * *}$ \\
\hline 2 & 99 & 240 & $8.0^{* *}$ & $41.3^{* * *}$ & $3.3^{* *}$ & $11.8^{* * *}$ \\
\hline 2a (Induced) & 83 & 224 & $7.5^{* *}$ & $37.1^{* * *}$ & $2.8^{* *}$ & $9.9^{* *}$ \\
\hline $2 b$ (Prelabor CS) & 16 & 16 & 0.5 & $100.00 \%$ & 0.5 & 1.9 \\
\hline 3 & 43 & 910 & $30.4^{* *}$ & $4.7^{* * *}$ & $1.4^{* * *}$ & 5.1 \\
\hline 4 & 52 & 351 & $11.7^{* * *}$ & $14.8^{* * *}$ & $1.7^{* * *}$ & $6.2^{* * *}$ \\
\hline $4 a$ (Induced) & 41 & 340 & $11.4^{* * *}$ & $12.1^{* * *}$ & $1.4^{* * *}$ & $4.9^{* * *}$ \\
\hline $4 b$ (Prelabor CS) & 11 & 11 & 0.4 & 100 & 0.4 & 1.3 \\
\hline 5 & 342 & 659 & $22.0^{* * *}$ & $51.9^{* * *}$ & $11.4^{* * *}$ & $40.7^{* * *}$ \\
\hline 5.a (1 CS) & 154 & 468 & $15.6^{* * *}$ & $32.9^{* * *}$ & $5.1^{* * *}$ & $18.3^{* * *}$ \\
\hline $5 . b(>1 \mathrm{CS})$ & 188 & 191 & $6.4^{* * *}$ & 98.4 & 6.3 & 22.4 \\
\hline 6 & 17 & 29 & $1.0^{* * *}$ & 58.6 & $0.6^{* *}$ & $2.0^{* * *}$ \\
\hline 7 & 92 & 136 & $4.5^{* * *}$ & $67.6^{* *}$ & $3.1^{* * *}$ & $10.9^{*}$ \\
\hline 8 & 44 & 104 & 3.5 & 42.3 & 1.5 & $5.2^{* * *}$ \\
\hline 9 & 10 & 10 & 0.3 & 100 & 0.3 & 1.2 \\
\hline 10 & 76 & 206 & $6.9^{* *}$ & $36.9^{* * *}$ & $2.5^{* * *}$ & 9 \\
\hline Total & 841 & 2991 & 100 & $28.1^{* * *}$ & 28.1 & 100 \\
\hline
\end{tabular}

* See groups description in Table 2

1. $\%=\mathrm{n}$ of women in the group / total $\mathrm{N}$ women delivered in the setting $\times 100$

2. $\%=\mathrm{n}$ of CS in the group / total $\mathrm{N}$ of women in the group $\times 100$

3. $\%=\mathrm{n}$ of $\mathrm{CS}$ in the group / total $\mathrm{N}$ of women delivered in the setting $\times 100$

4. $\%=n$ of CS in the group / total $N$ of CS in the setting $\times 100$

Comparisons using Chi square test with the normal weight groups, ${ }^{*} p<0.05,{ }^{* *} p<0.01,{ }^{* * *} p<0.001$

\section{Discussion}

\section{Main finding}

Women with obesity are more likely to deliver by CS compared to normal weight women and this trend was similar in each of the Robson classification group. The increase in the overall CS rate in case of maternal obesity is mostly explained by women presenting a history of previous CS (Robson group 5a). After adjustment for pregnancy complications and medical factors in group $5 \mathrm{a}$, the association between maternal obesity and CS before labor was not significant. However, maternal obesity remained an independent risk factor of in labor CS within this group.

\section{Interpretation}

This work suggests that in order to reduce the overall CS rate in women presenting maternal obesity we should focus on women with a history of a previous CS (Robson group 5a). Among women of group 5a, this analysis shows that the risk of CS before labor could be explained by medical factors and complications of pregnancy. Indeed, women with obesity were more likely to present high medical risk level at the beginning of pregancy and pregnancy complications that are not included in the Robson classification. Yet these conditions are relevant to discuss the mode of delivery. In that case the Robson classification might be of limited value to reduce the number of CS performed in obese women. Therefore, a better management of the pre-existing complications and planning for prenatal care and delivery by the obstetrical team would improve obstetrical outcomes by reducing the impact of pregnancy complications and the requirement of repeated CS before labor [12]. Indeed, recent works on nutritional management of patients with weight excess demonstrated that maintaining or even reducing pre-pregnancy BMI can limit the occurrence of pregnancy complication thanks to better total GWG management $[15,16]$.

The increase of in labor CS for women with obesity within group 5a was not explained by medical factors. Yet, the increase of adverse pregnancy outcomes with maternal BMI increase results in a higher rate of induction [17]. It has been demonstrated that failed induction was more frequent among obese women and that its occurrence was parallel to maternal BMI increase [18]. This could explain in part the increased in labor CS rate observed for women with obesity.

Moreover, the increase of in labor CS for arrest of labor in women with obesity observed in our study is consistent with the literature. Indeed, women with obesity have been shown to present an altered 
Table 4 neonatal outcomes of singleton pregnancies according to maternal pre-pregnancy BMl

\begin{tabular}{|c|c|c|c|}
\hline & $\begin{array}{l}\text { Normal weight } \\
N=11,316 \\
N(\%)\end{array}$ & $\begin{array}{l}\text { Obesity } \\
N=2886 \\
N(\%)\end{array}$ & $\mathrm{p}$ \\
\hline Birth weight (grams) (mean \pm sd) & $3233 \pm 568$ & $3313 \pm 688$ & $<0.001$ \\
\hline Birth weight (grams) & & & $<0.001$ \\
\hline$[2500-3800[$ & $8981(79.4)$ & $2011(69.7)$ & \\
\hline$<2500$ & $850(7.5)$ & $252(8.7)$ & \\
\hline$>3800$ & $1485(13.1)$ & $623(21.6)$ & \\
\hline $\mathrm{pH}$ at ombilical cord & & & $<0.001$ \\
\hline $\mathrm{pH}<7$ & $36(0.3)$ & $19(0.7)$ & \\
\hline $\mathrm{pH}[1,7]$ & $150(1.4)$ & $64(2.3)$ & \\
\hline $\mathrm{pH}] 7.1-7.2[$ & 709 (6.4) & $179(6.3)$ & \\
\hline $\mathrm{pH} \geq 7.2$ & $10,185(91.9)$ & $2558(90.7)$ & \\
\hline Apgar score $<7$ at $5 \mathrm{~min}$ & $132(1.2)$ & $68(2.4)$ & $<0.001$ \\
\hline Neonatal transfer & & & $<0.001$ \\
\hline Neonatal reanimation unit & $443(3.9)$ & $175(6.1)$ & \\
\hline Intensive care unit & $622(5.5)$ & $223(7.8)$ & \\
\hline Other specialized services & $65(0.6)$ & $20(0.7)$ & \\
\hline
\end{tabular}

first phase of labor and an increase in labor obstruction $[19,20]$. This point might be due to a less effective myometrium in term of contractility [21] or a decrease in oxytocin receptors parallel to maternal BMI increase [22] and a higher blood rate of Leptin and cholesterol impairing myometrial contractility [23].

The main strength of this study is that it identified the characteristics of women with obesity responsible for the overall CS rate increase for the first time. A large number of women was included which allows to have a power necessary to highlight a difference between the maternal BMI groups if it exists. Attending practitioners prospectively collected the data about the management of the pregnancy, labor and delivery, and these data were ascertained routinely by medical staff the day after the delivery, so that thorough and accurate information was available for adjustment in the multiple logistic regression models. Moreover, the collection of induction indications and CS indications allowed a better understanding of the differences observed thanks to the Robson classification pertinence in the analyses of CS profiles.

The unicentric design of the study can limit the generalization of the results. Moreover, this study was conducted in an institution that present a lower CS rate compared to the average national rate [2] and all women who presented a history of one CS were encouraged to labor. Finally, few data about the characteristics of labor were analyzed including the cervical dilation at which the CS occurred.

Although, women with a BMI $\geq 30$ have an increased rate of in labor CS, most of them undergo planned CS for a history of two or more CS. In order to reduce the CS rate in this population we should first improve prenatal care and nutritional management to avoid repeated CS before labor. Secondly, further studies must focus on the labor of women with a history of one CS (Robson group 5a) to identify risk factors of repeated CS.

\section{Supplementary Information}

The online version contains supplementary material available at https://doi. org/10.1186/s12884-020-03410-z.

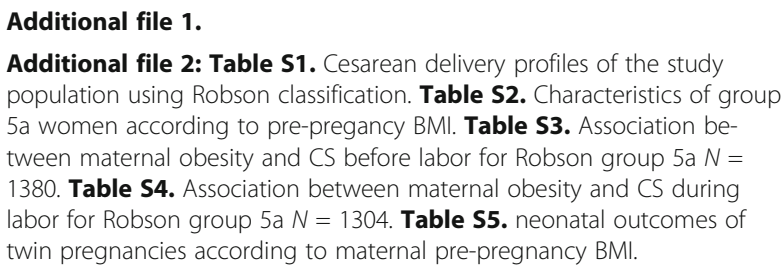

Abbreviations

BMI: Body mass index; CS: Cesarean section; GWG: Gestational weight gain

\section{Acknowledgements}

Not Applicable.

\section{Authors' contributions}

SC and DK worked on data collection, statistical analyses, study design and writing of the manuscript. CM contributed to data collection and commented on the manuscript. OS and TS designed the study and reviewed the paper before publication. All authors have read and approved the manuscript.

\section{Funding}

This research did not receive any specific grant from funding agencies in the public, commercial, or not-for-profit sectors.

\section{Availability of data and materials}

Raw data including the database are available in the supplementary files.

\section{Ethics approval and consent to participate}

This study database was approved by the National Data Protection Authority (Commission Nationale de l'Informatique et des Libertes, CNIL no. 293683).

This observational study waived the need to obtain informed consent according to the French law. The study was approved by Robert-Debré hospital ethic committee. Women were informed that their records could be used for the evaluation of medical practices and were allowed to opt out of these studies.

\section{Consent for publication}

Not Applicable.

\section{Competing interests}

The authors declared no conflict of interest.

\section{Author details}

'Department of Gynecology and Obstetrics, Robert Debré University Hospital, AP-HP, 48 boulevard Sérurier, 75019 Paris, France. ${ }^{2}$ Centre for Epidemiology and Statistics Sorbonne Paris Cité (CRESS), Obstetrical Perinatal and Pediatric Epidemiology Research Team, EPOPé, INSERM, INRA, Université de Paris, Paris, France. 
Received: 9 August 2020 Accepted: 10 November 2020

Published online: 26 November 2020

\section{References}

1. Blondel B, Kermarrec M. French national perinatal survey; 2010. n.d.:52

2. Blondel B, Coulm B, Bonnet C, Goffinet F, Le Ray C. Trends in perinatal health in metropolitan France from 1995 to 2016: results from the French National Perinatal Surveys. J Gynecol Obstet Hum Reprod. 2017;46:701-13. https://doi.org/10.1016/j.jogoh.2017.09.002.

3. Fisher SC, Kim SY, Sharma AJ, Rochat R, Morrow B. Is obesity still increasing among pregnant women? Prepregnancy obesity trends in 20 states, 20032009. Prev Med. 2013;56:372-8. https://doi.org/10.1016/j.ypmed.2013.02.015.

4. Deputy NP, Dub B, Sharma AJ. Prevalence and trends in Prepregnancy Normal weight - 48 states, new York City, and District of Columbia, 20112015. MMWR Morb Mortal Wkly Rep. 2018;66:1402-7. https://doi.org/10. 15585/mmwr.mm665152a3.

5. Fuchs F, Senat M-V, Rey E, Balayla J, Chaillet N, Bouyer J, et al. Impact of maternal obesity on the incidence of pregnancy complications in France and Canada. Sci Rep. 2017;7. https://doi.org/10.1038/s41598-017-11432-5.

6. Kristensen J, Vestergaard M, Wisborg K, Kesmodel U, Secher NJ. Prepregnancy weight and the risk of stillbirth and neonatal death. BJOG Int J Obstet Gynaecol. 2005;112:403-8. https://doi.org/10.1111/j.1471-0528.2005. 00437.x.

7. Heslehurst N, Simpson H, Ells LJ, Rankin J, Wilkinson J, Lang R, et al. The impact of maternal BMI status on pregnancy outcomes with immediate short-term obstetric resource implications: a meta-analysis. Obes Rev. 2008; 9:635-83. https://doi.org/10.1111/j.1467-789X.2008.00511.x.

8. Weiss JL, Malone FD, Emig D, Ball RH, Nyberg DA, Comstock CH, et al. Obesity, obstetric complications and cesarean delivery rate-a populationbased screening study. Am J Obstet Gynecol. 2004;190:1091-7. https://doi. org/10.1016/j.ajog.2003.09.058.

9. Robillard P-Y, Hulsey TC, Boukerrou M, Bonsante F, Dekker G, lacobelli S. Linear association between maternal age and need of medical interventions at delivery in primiparae: a cohort of 21,235 singleton births. J Matern Fetal Neonatal Med. 2017:1-1. https://doi.org/10.1080/14767058.2017.1334049.

10. Ehrenberg HM, Durnwald CP, Catalano P, Mercer BM. The influence of obesity and diabetes on the risk of cesarean delivery. Am J Obstet Gynecol. 2004;191:969-74. https://doi.org/10.1016/j.ajog.2004.06.057.

11. Robson M. Classification of caesarean sections. Fetal Matern Med Rev. 2001; 12. https://doi.org/10.1017/S0965539501000122.

12. American College of Obstetricians and Gynecologists. Obesity in pregnancy. Committee opinion no. 549. Obstet Gynecol. 2013;121:213-7. https://doi. org/10.1097/01.AOG.0000425667.10377.60.

13. Collège National des Gynécologues et Obstétriciens Français. Gestational diabetes. J Gynecol Obstet Biol Reprod. 2010;39:S338-42. https://doi.org/10. 1016/S0368-2315(10)70058-2

14. Wu Y, Kataria $Y$, Wang Z, Ming W-K, Ellervik C. Factors associated with successful vaginal birth after a cesarean section: a systematic review and meta-analysis. BMC Pregnancy Childbirth. 2019;19:360. https://doi.org/10. 1186/s12884-019-2517-y.

15. Teulings NEWD, Masconi KL, Ozanne SE, Aiken CE, Wood AM. Effect of interpregnancy weight change on perinatal outcomes: systematic review and meta-analysis. BMC Pregnancy Childbirth. 2019;19:386. https://doi.org/ 10.1186/s12884-019-2566-2.

16. Harvey MW, Braun B, Ertel KA, Pekow PS, Markenson G, Chasan-Taber L. Prepregnancy body mass index, gestational weight gain, and odds of cesarean delivery in Hispanic women: gestational weight gain and cesarean delivery. Obesity. 2018;26:185-92. https://doi.org/10.1002/oby.22048.

17. Ruhstaller K. Induction of labor in the obese patient. Semin Perinatol. 2015; 39:437-40. https://doi.org/10.1053/j.semperi.2015.07.003.

18. Wolfe KB, Rossi RA, Warshak CR. The effect of maternal obesity on the rate of failed induction of labor. Am J Obstet Gynecol. 2011;205:128.e1-7. https://doi.org/10.1016/j.ajog.2011.03.051.

19. Norman SM, Tuuli MG, Odibo AO, Caughey AB, Roehl KA, Cahill AG. The effects of obesity on the first stage of labor. Obstet Gynecol. 2012;120:1305. https://doi.org/10.1097/AOG.0b013e318259589c.

20. Vahratian A, Zhang J, Troendle JF, Savitz DA, Siega-Riz AM. Maternal Prepregnancy overweight and obesity and the pattern of labor progression in term nulliparous women. Obstet Gynecol. 2004;104:943-51. https://doi. org/10.1097/01.AOG.0000142713.53197.91
21. Zhang J, Bricker L, Wray S, Quenby S. Poor uterine contractility in obese women. BJOG Int J Obstet Gynaecol. 2007;114:343-8. https://doi.org/10. 1111/j.1471-0528.2006.01233.x.

22. Grotegut CA, Gunatilake RP, Feng L, Heine RP, Murtha AP. The influence of maternal body mass index on Myometrial oxytocin receptor expression in pregnancy. Reprod Sci. 2013;20:1471-7. https://doi.org/10.1177/ 1933719113488446

23. Wuntakal R, Kaler M, Hollingworth T. Women with high BMI: should they be managed differently due to antagonising action of leptin in labour? Med Hypotheses. 2013;80:767-8. https://doi.org/10.1016/j.mehy.2013.03.006.

\section{Publisher's Note}

Springer Nature remains neutral with regard to jurisdictional claims in published maps and institutional affiliations.
Ready to submit your research? Choose BMC and benefit from:

- fast, convenient online submission

- thorough peer review by experienced researchers in your field

- rapid publication on acceptance

- support for research data, including large and complex data types

- gold Open Access which fosters wider collaboration and increased citations

- maximum visibility for your research: over $100 \mathrm{M}$ website views per year

At BMC, research is always in progress.

Learn more biomedcentral.com/submissions 